75 years of Agricultural University - Plovdiv

JUBILEE SCIENTIFIC INTERNATIONAL

CONFERENCE Plovdiv 26-28 November 2020
PERSPECTIVES ON AGRICULTURAL SCIENCE AND INNOVATIONS FOR SUSTAINABLE FOOD SYSTEMS

\title{
DOI: 10.22620 /agrisci.2021.30.005 \\ THE MORPHOLOGICAL AND BIOLOGICAL CHARACTERISTICS OF THE SPECIMENS FROM MONARDA DIDYMA
}

\author{
Nadejda Zapryanova*, Stela Dimkova, Ralitsa Gavrilova \\ Institute of Ornamental and Medicinal Plants-Sofia 1222 \\ *E-mail: nadejda_zaprianova@abv.bg
}

\begin{abstract}
The plants of the genus Monarda of the family Lamiaceae are little known in our country. The species Monarda didyma is mainly distributed. It is used in landscaping as a perennial ornamental crop. In addition to its original blossoms, it has a pleasant aroma combining the aromas of bergamot, lemon and mint, due to the essential oils contained in the leaves, blossoms and stems of the plant.

The Institute of Ornamental and Medicinal Plants - Sofia has a perennial species collection in which the genus Monarda is represendted by 32 genotypes of the Monarda didyma species. The plants are characterized by different habit, color and shape of the blossoms. During the phenological observations it was established that in the Sofia field region the Monarda vegetation begins in the beginning of March and ends in the beginning of October. The flowering period in almost all samples covers the months of June to August, with mass flowering in the beginning of July. Biometric measurements show differences in the size of the tufts formed, the size of the leaves and the flowers.

After analyzes, genotypes with emphasized decorative qualities were separated, which will be used to diversify the range of seedlings in the Monarda didyma type offered on the market.
\end{abstract}

Key words: Monarda didyma, habit, blossoms, phenological observations, flowering period

\section{INTRODUCTION}

The production of ornamental plants is expanding every year. Currently the world market for these crops is estimated at about 107 billion dollars a year. Such an assessment emphasizes the importance of the sector for the economy of countries, as well as its important social role related to income and employment (Aguirre, 2007, Botelho et al., 2015, Silva, et al. 2018).

In recent years, the need to diversify the range of ornamental species for the garden is constantly growing and this requires looking for crops with original shape and color, pleasant aroma and resistance to abiotic and biotic environmental conditions.

Ornamental gardening is the sector of modern agriculture responsible for the commercialization of hundreds of species from many botanical families, including exotic or native landscape and houseplants (Heywood, 2001, Anderson, 2007). The success of new flower products on the market can be increased if the desired qualities are determined by specific criteria such as: the morphological characteristics of the plant in terms of its novelty or aesthetic value.

The decorative value of the plant is no longer the only criteria needed to make it commercially successful. There is a renewed interest in the old ornamental crops that possess drought tolerance and disease resistance, continuous flowering or healing properties (Wilkins and Anderson, 2007; Stumpf, et al. 2012, Tognon and Cuquel, 2016).

The Monarda genus is named after the Spanish physician and botanist Nicolaus Minardes (1493-1578), who originally studied it. Species of this genus naturally inhabit North 
75 years of Agricultural University - Plovdiv JUBILEE SCIENTIFIC INTERNATIONAL CONFERENCE Plovdiv 26-28 November 2020
PERSPECTIVES ON AGRICULTURAL SCIENCE AND INNOVATIONS FOR SUSTAINABLE FOOD SYSTEMS
America from Canada to Mexico. They have been imported and cultivated in Europe since the 18th century. The species $M$. citriodora, $M$. didyma, Monarda fruticulosa and M. fistulosa are known in agriculture (Davidson, 2007). Most hybrids on the market are derived from intra- and interspecific crosses of M. didyma and M. fistulosa. Varieties and hybrids vary depending on the color, height of the plant and disease resistance (Davidson, 2007, Korablyova, Lynx, 2013, Feskov and Shevchuk 2017). Powdery mildew (Erysiphe monardae) and rust (Puccinia menthae Pers.) are the most common diseases observed in landscape crops (Collicutt and Davidson 1999). Powdery mildew that attacks the Monarda should be considered a fungal disease of economic significance. The symptoms of the disease consist of powdery mildew which grows spots on the leaf mass, and in some cases when the attack is stronger the spots appear on the stems. The leaves turn yellow and dry out and this leads to a decrease in the decorative qualities of the plants (Dudchenko, et al (2020). In recent years, the Monarda selection program has focused on creating varieties or hybrids with compact shape, large flowers, resistance to disease and increased content of essential oils (Collicutt \& Davidson, 1999, Dudchenko, et al, 2020). The representatives of the Monarda genus of the family Lamiaceae are little known in our country, mainly as perennial ornamental plants. The species Monarda didyma is widespread (Shtilyanova, 2005). In addition to its decorative flower, which makes it an interesting crop used in flowering gardens, it has a pleasant aroma combining the scent of bergamot, lemon and mint which come from the essential oils contained in the leaves, flowers and stems of the plant.

The aim of the present study is to analyze the decorative qualities of 32 specimens of Monarda didyma, grown under specific conditions in the Sofia field.

\section{MATERIALS AND METHODS}

The study was conducted in IDLR-Sofia in 2019-2020. The seed material from Monarda didyma originates from Poland. The seeds were sown in March 2019 in tarins in a mixture of: peat: soil: perlite (2: $1: 0.5)$. The obtained seeds were dipped at the beginning of May 2019 in pots №9 in the same mixture.

In October 2019, they were transferred only to soil in pots №15. The plants overwintered in an unheated greenhouse. At the beginning of April 2020 they were planted on a permanent place in the collection of perennial species of IDLR-Sofia.

With the onset of vegetation, the following observations were made:

- Phenological - initial, mass and final manifestation of the phenophases budding and flowering. It was assumed that the date a plant enters initial stage is $15 \%$ and $80 \%$ for the mass stage.

- Biometric - height and width of the plants, number of formed peduncles, total number of flowers, diameter of the flower, color of the flower.

- Resistance to the causative agent of powdery mildew / Erysiphe monardae /. The type of reaction of the studied genotypes to the powdery mildew pathogen was tested against a natural background of infection and was assessed by a 4-point system depending on the percentage of leaves with typical symptoms: (1) resistant - leaves are free from powdery mildew, ( 2) moderately resistant - up to $25 \%$ of the leaves have symptoms of the disease, (3) moderately sensitive - up to $50 \%$ of the leaves have symptoms, (4) sensitive - over $50 \%$ of the leaves have symptoms (Naidenova and Bozhanska, 2014).

\section{RESULTS AND DISCUSSION}

Phenological observations show that in the region of IDLR-Sofia the beginning of 
75 years of Agricultural University - Plovdiv JUBILEE SCIENTIFIC INTERNATIONAL CONFERENCE Plovdiv 26-28 November 2020
PERSPECTIVES ON AGRICULTURAL SCIENCE AND INNOVATIONS FOR SUSTAINABLE FOOD SYSTEMS vegetation is considered to be the beginning of March 2020 (Table 1). The plants formed a tuft of many new shoots, some of which in May 2020 were formed into flowering stems.
The beginning of budding in most samples began in early June 2020, and the first flowers were formed 15 days later (Table 1 ).

Table 1. Phenological observations of Monarda didyma genotypes in 2019/2020

\begin{tabular}{|c|c|c|c|c|c|c|c|c|}
\hline \multirow{2}{*}{ № } & \multicolumn{2}{|c|}{ Vegetation } & \multicolumn{2}{|c|}{ Budding } & \multicolumn{4}{|c|}{ Flowering } \\
\hline & beginning & closing & beginning & mass & beginning & mass & closing & Duration days \\
\hline 1 & $01 .-10.03$ & $15-30.10$ & 29.05 & 22.06 & 26.06 & 09.07 & 08.09 & 75 \\
\hline 2 & $01 .-10.03$ & $15-30.10$ & 15.06 & 22.06 & 09.07 & 13.07 & 20.08 & 43 \\
\hline 3 & $01 .-10.03$ & $15-30.10$ & 08.06 & 22.06 & 01.07 & 06.07 & 21.09 & 83 \\
\hline 4 & $01 .-10.03$ & $15-30.10$ & & - & - & - & - & - \\
\hline 5 & $01 .-10.03$ & $15-30.10$ & 15.06 & 30.06 & 06.07 & 20.07 & 17.09 & 74 \\
\hline & $01 .-10.03$ & $15-30.10$ & 15.06 & 30.06 & 13.07 & 05.08 & 17.09 & 67 \\
\hline 6 & $01 .-10.03$ & $15-30.10$ & 25.06 & 06.07 & 20.07 & 28.07 & 14.09 & 57 \\
\hline 7 & $01 .-10.03$ & $15-30.10$ & 04.06 & 22.06 & 30.06 & 06.07 & 3.10 & 96 \\
\hline 8 & $01 .-10.03$ & $15-30.10$ & 06.07 & 13.07 & 25.07 & 05.08 & 28.09 & 66 \\
\hline 9 & $01 .-10.03$ & $15-30.10$ & - & - & - & - & - & - \\
\hline 10 & $01 .-10.03$ & $15-30.10$ & - & - & - & - & - & - \\
\hline 11 & $01 .-10.03$ & $15-30.10$ & 08.06 & 30.06 & 25.06 & 13.07 & 09.09 & 77 \\
\hline 12 & $01 .-10.03$ & $15-30.10$ & 17.06 & 22.06 & 10.07 & 13.07 & 09.09 & 62 \\
\hline 13 & $01 .-10.03$ & $15-30.10$ & 25.06 & 26.06 & 13.07 & 16.07 & 10.09 & 60 \\
\hline 14 & $01 .-10.03$ & $15-30.10$ & 08.06 & 25.06 & 06.07 & 09.07 & 17.09 & 74 \\
\hline 15 & $01 .-10.03$ & $15-30.10$ & 22.06 & 30.06 & 13.07 & 20.07 & 05.10. & 85 \\
\hline 16 & $01 .-10.03$ & $15-30.10$ & 22.06 & 30.06 & 13.07 & 17.07 & 13.08 & 32 \\
\hline 17 & $01 .-10.03$ & $15-30.10$ & & - & - & - & - & - \\
\hline 18 & $01 .-10.03$ & $15-30.10$ & 26.06 & 06.07 & 20.07 & 28.07 & 27.08 & 39 \\
\hline 19 & $01 .-10.03$ & $15-30.10$ & 22.06 & 30.06 & 13.07 & 20.07 & 28.09 & 47 \\
\hline 20 & $01 .-10.03$ & $15-30.10$ & & - & - & - & - & - \\
\hline 21 & $01 .-10.03$ & $15-30.10$ & 29.05 & 22.06 & 30.06 & 06.07 & 05.08 & 68 \\
\hline 22 & $01 .-10.03$ & $15-30.10$ & & - & - & - & - & - \\
\hline 23 & $01 .-10.03$ & $15-30.10$ & 12.06 & 30.06 & 06.07 & 13.07 & 03.10 & 90 \\
\hline 24 & $01 .-10.03$ & $15-30.10$ & 08.06 & 06.07 & 30.06 & 28.07 & 08.09 & 71 \\
\hline 25 & $01 .-10.03$ & $15-30.10$ & 25.06 & 09.07 & 13.07 & 28.07 & 05.10 & 85 \\
\hline 26 & $01 .-10.03$ & $15-30.10$ & 02.06 & 12.06 & 22.06 & 06.07 & 03.09 & 74 \\
\hline 27 & $01 .-10.03$ & $15-30.10$ & 22.06 & 09.07 & 13.07 & 20.07 & 05.08 & 24 \\
\hline 28 & $01 .-10.03$ & $15-30.10$ & 25.06 & 30.06 & 20.07 & 28.07 & 11.09 & 54 \\
\hline 29 & $01 .-10.03$ & $15-30.10$ & 06.07 & 20.07 & 28.07 & 05.08 & 05.10 & 70 \\
\hline 30 & $01 .-10.03$ & $15-30.10$ & $25.06-$ & 30.06 & 18.07 & 20.07 & 20.08 & 34 \\
\hline 31 & $01 .-10.03$ & $15-30.10$ & - & - & - & - & - & - \\
\hline 32 & $01 .-10.03$ & $15-30.10$ & 12.06 & 22.06 & 06.07 & 13.07 & 28.09 & 85 \\
\hline
\end{tabular}

The mass flowering was in July 2020. The duration of the flowering period was on average about 50-70 days. Genotype 27 was characterized by the shortest flowering period of 24 days, and genotype 7 by the longest -96 days. No blooms were observed in genotypes 4 , 9, 10, 11, 20, 28 and 29, although the plants bloomed in the second year after sowing.

Later flowering varieties were also created, in which flowering begins in late July and lasts until the end of August, lasting 6-8 weeks (Collicutt and Davidson, 1999). The vegetation period usually lasts for 170-200 days, and its duration depends on the conditions 
75 years of Agricultural University - Plovdiv JUBILEE SCIENTIFIC INTERNATIONAL CONFERENCE Plovdiv 26-28 November 2020
PERSPECTIVES ON AGRICULTURAL SCIENCE AND INNOVATIONS FOR SUSTAINABLE FOOD SYSTEMS of the area in which it is grown (Bedulenko, 2013). For the region of the Sofia field, the Monarda vegetation ends at the end of October. In the biometric which was made, the examined samples varied in height from 30 to $97 \mathrm{~cm}$ and a difference in 40 to $70 \mathrm{~cm}$ was established. The mass size of the samples was about $70 / 60 \mathrm{~cm}$ (height / width) (Table 2). Samples 10 and 20 had the most compact form (Table 2).

Many researchers have noted in their observations that the habitat of plants varies from 60 to $120 \mathrm{~cm}$ depending on the conditions under which the Korablyova culture is grown. (Lynx (2013). Bedulenko, (2013) Feskov, Shevchuk (2017. Dudchenko, et al. (2020).

Varieties have been created for the needs of gardening that have a more compact shape, with a size of $25 / 30 \mathrm{~cm}$ - such as Petite Delight 'Collicutt, Davidson (1999) and Victoria variety - 30 / 40cm Can L (1996). The flowers of the Monarda are collected in complex apical inflorescences with a spherical shape, and their size varies from 5.5 to $8.5 \mathrm{~cm}$.

Table 2. Biometric observations of the qualitative indicators of Monarda didyma genotypes in $2019 / 2020$

\begin{tabular}{|c|c|c|c|c|c|c|c|}
\hline \multirow[t]{2}{*}{ № } & \multirow{2}{*}{$\begin{array}{c}\text { Height } \\
\text { cm }\end{array}$} & \multirow{2}{*}{$\begin{array}{c}\text { Width } \\
\text { cm }\end{array}$} & \multirow{2}{*}{$\begin{array}{c}\text { Flowering } \\
\text { stems }\end{array}$} & \multirow[t]{2}{*}{ Flowers } & \multicolumn{2}{|c|}{ Diameter flower } & \multirow[t]{2}{*}{ Color flower } \\
\hline & & & & & single & double & \\
\hline 1 & 74,5 & 55 & 9 & 13 & 7,1 & - & light pink \\
\hline 2 & 81,2 & 59 & 8 & 10 & 7 & - & cyclamen-purple \\
\hline 3 & 97,9 & 58,2 & 2 & 12 & 7,1 & 5,2 & $\begin{array}{l}\text { cyclamen } \\
\text { purple }\end{array}$ \\
\hline 4 & 52,2 & 49,6 & - & - & - & - & - \\
\hline 5 & 81 & 70,3 & 7 & 7 & 7,2 & - & light cyclamen \\
\hline 6 & 82,1 & 43,3 & 6 & 7 & 6,4 & 5,1 & light pink \\
\hline 7 & 85,6 & 69,8 & 5 & - & - & - & - \\
\hline 8 & 80,1 & 60,1 & 7 & 17 & 7,6 & 4,5 & light cyclamen \\
\hline 9 & 48,1 & 39,5 & - & - & - & - & - \\
\hline 10 & 31,1 & 40,1 & - & - & - & - & - \\
\hline 11 & 58,2 & 55,2 & - & - & - & - & - \\
\hline 12 & 90,3 & 67,6 & 3 & 10 & 7,4 & - & dark cyclamen \\
\hline 13 & 82,3 & 51,1 & 5 & 20 & 7,2 & 3,3 & pink \\
\hline 14 & 95,2 & 46,4 & 1 & 2 & 6,5 & - & dark purple \\
\hline 15 & 70,9 & 59,4 & 7 & 13 & 8,5 & 6,6 & pink \\
\hline 16 & 80,6 & 55,7 & 6 & 10 & 6,3 & 4,1 & light violet \\
\hline 17 & 70,3 & 50,3 & 2 & 3 & 5,3 & - & pink \\
\hline 18 & 90,7 & 55,3 & - & - & - & - & - \\
\hline 19 & 88,9 & 57,4 & 3 & 5 & 6,7 & $\mathbf{1 , 9}$ & crimson pink \\
\hline 20 & 30,1 & 45,2 & - & - & - & - & - \\
\hline 21 & 46,9 & 47,9 & 3 & 9 & 6,9 & - & light pink \\
\hline 22 & 37,3 & 32,1 & - & - & - & - & - \\
\hline 23 & 65,3 & 60,2 & 8 & 7 & 7,8 & 4,2 & light cyclamen \\
\hline 24 & 59,6 & 60,1 & 1 & 9 & 7,4 & - & light cyclamen \\
\hline 25 & 56,4 & 40,3 & 2 & 5 & 6,3 & - & dark purple \\
\hline 26 & 61,3 & 57,5 & 5 & 12 & 8,2 & - & dark purple \\
\hline 27 & 71,9 & 57,2 & 1 & 5 & 5,9 & - & pink cyclamen \\
\hline 28 & 78,6 & 63,6 & - & - & - & - & - \\
\hline 29 & 66,2 & 61,3 & - & - & - & - & - \\
\hline 30 & 95,7 & 45,6 & 6 & 10 & 6,3 & - & pink \\
\hline 31 & 61,3 & 41,3 & - & - & - & - & - \\
\hline 32 & 92,1 & 50 & 6 & 15 & 7,2 & - & pale pink \\
\hline
\end{tabular}


75 years of Agricultural University - Plovdiv JUBILEE SCIENTIFIC INTERNATIONAL

CONFERENCE Plovdiv 26-28 November 2020
PERSPECTIVES ON AGRICULTURAL SCIENCE AND INNOVATIONS FOR SUSTAINABLE FOOD SYSTEMS
Samples with the size of the flowers in diameter 6-7 $\mathrm{cm}$ predominated in the collection of IDLR-Sofia (Table 2). Some of the plants had double, triple and quadruple flowers. They formed on stems coming from the original color, forming cymose inflorescences. The size of the additionally shaped colors decreased compared to the original, as their size was from 1.9 to 6.6 $\mathrm{cm}$. Sample №15 in the IDLR collection with the largest colors had a size of $8.5 / 6.6 \mathrm{~cm}$ (Table 2).

Table 3. Biometric observations of the leaves of Monarda didyma genotypes in 2019/2020

\begin{tabular}{|c|c|c|c|c|}
\hline № & $\begin{array}{c}\text { Height } \\
\text { cm }\end{array}$ & $\begin{array}{c}\text { Width } \\
\text { cm }\end{array}$ & Form & Hair formation \\
\hline 1 & 6,4 & $\mathbf{3 , 0}$ & broadly lanceolate & - \\
\hline 2 & 5,3 & 3,0 & broadly lanceolate & yes-weak \\
\hline 3 & 5,4 & 2,5 & broadly lanceolate & - \\
\hline 4 & 5 & 2,3 & broadly lanceolate & - \\
\hline 5 & 6,4 & 2,9 & broadly lanceolate & - \\
\hline 6 & 5,8 & 2,9 & broadly lanceolate & yes \\
\hline 7 & 4,0 & 1,7 & broadly lanceolate & yes \\
\hline 8 & 6,1 & 2,8 & broadly lanceolate & yes \\
\hline 9 & 5,6 & 2,3 & broadly lanceolate & - \\
\hline 10 & 5,7 & 2,6 & broadly lanceolate & - \\
\hline 11 & 4,3 & 2,0 & broadly lanceolate & - \\
\hline 12 & 5,4 & 2,7 & broadly lanceolate & - \\
\hline 13 & 5,9 & 2,7 & broadly lanceolate & yes-weak \\
\hline 14 & 5,3 & 3,0 & broadly lanceolate & yes \\
\hline 15 & 5,9 & 2,1 & broadly lanceolate & yes-weak \\
\hline 16 & 5,8 & 2,9 & broadly lanceolate & yes-weak \\
\hline 17 & 5,6 & 3,4 & broadly lanceolate & - \\
\hline 18 & 5,6 & 2,8 & broadly lanceolate & - \\
\hline 19 & 5,7 & 2,6 & broadly lanceolate & - \\
\hline 20 & 4,4 & 2,1 & broadly lanceolate & yes \\
\hline 21 & 5,4 & 3,1 & broadly lanceolate & yes-weak \\
\hline 22 & 5,7 & 3,8 & broadly lanceolate & - \\
\hline 23 & 5,9 & 3,0 & broadly lanceolate & - \\
\hline 24 & 5,0 & 3,0 & broadly lanceolate & yes-weak \\
\hline 25 & 5,7 & 3,0 & broadly lanceolate & yes \\
\hline 26 & 5,9 & 2,9 & broadly lanceolate & - \\
\hline 27 & 5,4 & 3,3 & broadly lanceolate & yes-weak \\
\hline 28 & 6,4 & 2,9 & broadly lanceolate & - \\
\hline 29 & 4,5 & 3,0 & broadly lanceolate & - \\
\hline 30 & 5,0 & 3,8 & broadly lanceolate & yes-weak \\
\hline 31 & 5,7 & 3,1 & broadly lanceolate & yes \\
\hline 32 & 5,7 & 3,0 & broadly lanceolate & - \\
\hline 33 & 6,3 & 2,9 & broadly lanceolate & - \\
\hline 34 & 5,8 & 2,7 & broadly lanceolate & yes \\
\hline 35 & 6,2 & 2,4 & broadly lanceolate & - \\
\hline 36 & 5,9 & 3,7 & broadly lanceolate & yes-weak \\
\hline
\end{tabular}

In the collections of different botanical gardens in Russia and Ukraine, the size of the inflorescences varies on average about $5-7 \mathrm{~cm}$
(Feskov, Shevchuk, 2017, Dudchenko, et al 2020). There are hybrids and varieties with smaller flowers 2.5-4 cm (Can L, 1996). The 
75 years of Agricultural University - Plovdiv JUBILEE SCIENTIFIC INTERNATIONAL CONFERENCE Plovdiv 26-28 November 2020
PERSPECTIVES ON AGRICULTURAL SCIENCE AND INNOVATIONS FOR SUSTAINABLE FOOD SYSTEMS predominant color of the Monarda specimens in IDLR-Sofia was pink cyclamen. Interest was provoked by the wine color of №14, 25 and 26 and the raspberry pink color of №19. Specimens in red and white were not found in the IDLR collection. The world collections are dominated by pink, pink-violet and purple (Davidson, 2007, Feskov, Shevchuk, 2017, Dudchenko, et al 2020).

The leaf mass of the Monarda genotypes in IDLR-Sofia was dark green. The shape of the leaves did not differ from one number to another. In all genotypes it was broadly lanceolate. The largest size - $6.4 / 3 \mathrm{~cm}$ (length / width) was characterized by the numbers: 1,5 and 28, and the smallest was the number $7-4$ /
$1.7 \mathrm{~cm}$ (length / width) (Table 3). The formation of pappus was observed on the leaf blade, but the amount of plant heirs may be strong or less pronounced. In the collection the number with and without plant hairs on the leaf blade was equal to the samples (Table 3 ).

The attack of powdery mildew against a natural background of infection was observed mainly in May, June and July. Table 5 presents the distribution of samples using the four-point system depending on the percentage of leaves with typical symptoms. The results show that the majority of the Monarda specimens belonged to the group of moderately resistant, in which pathogen damage covers $25 \%$ of the leaf mass.

Table 4. Reaction to powdery mildew of Monarda didyma genotypes in 2019/2020

\begin{tabular}{|c|c|c|}
\hline Reaction & $\begin{array}{c}\text { Number } \\
\text { of } \\
\text { samples }\end{array}$ & № \\
\hline 1 - resistant & 1 & 25 \\
\hline 2 - moderately resistant & 21 & $4,5,6,7,9,10,14,15,16,17,20,21,22,23,24,26,27,29,30,31$ \\
\hline 3 - moderately sensitive & 6 & $1,11,12,19,28,32$ \\
\hline 4 - sensitive & 4 & $2,3,8,13$ \\
\hline
\end{tabular}

\section{CONCLUSIONS}

After the evaluation of 32 specimens of Monarda didyma, plants with potential decorative qualities were found, which would find a place in the landscape planting. These specimens have a more compact shape, as the specimens №10 and 20 have larger colors the same as № 15 and 26. They have spectacular color dye as № 14,19,25 and 26, a longer flowering period as № 7 and 23 and resistance to powdery mildew pathogen such as № 25 . Concerning the future production of the planting material the following samples present an interest:

Sample №25 characterized by a compact shape 56.4 / $40.3 \mathrm{~cm}$ (height / width), wine color, the formation of double colors and resistance to powdery mildew. Sample №21 had a weak growth - up to $47 \mathrm{~cm}$ in height, its flowers were large with a diameter of $6.9 \mathrm{~cm}$ and was characterized by medium resistance to powdery mildew. Sample №15 formed large flowers $8.5 \mathrm{~cm}$ (single and double), with a deep pink color and medium resistance to powdery mildew.

In order to preserve the valuable decorative qualities, the samples will be multiplied vegetatively in the laboratory complex of IDLR-Sofia.

\section{REFERENCES}

Aguirre P., 2007. Protection. In: Anderson N.O. (eds) Flower Breeding and Genetics. pp 81-112 DOI: 10.1007/978-1-4020-4428$1 \_4$

Anderson N., 2007. Prevention of Invasiveness in Floricultural Crops. In: Anderson N.O. (eds) Flower Breeding and Genetics. Springer, Dordrecht. https://doi.org/10.1007/978-1-4020- 
75 years of Agricultural University - Plovdiv JUBILEE SCIENTIFIC INTERNATIONAL CONFERENCE Plovdiv 26-28 November 2020
PERSPECTIVES ON AGRICULTURAL SCIENCE AND INNOVATIONS FOR SUSTAINABLE FOOD SYSTEMS
4428-1_6

Bedulenko A.2013. Introduktsiia, ekologicheskii aspekt i sovremennye napravleniia izucheniia i primeneniia lekarstvennogo, priano-aro-maticheskogo efirnomaslichnogo rasteniia Monarda fistulosa L.. Trudy Belorusskogo gosudarstvennogo uni-versiteta. 8(2):5260. [cited 2020 Apr 20]. УДК 633.88

Botelho, F., Rodrigues, C., Bruzi, A., 2015. Ornamental plant breeding. Ornamental Horticulture, 21(1), 9-16. https://doi.org/10.14295/rbho.v21i1.770

Collicutt, L., Davidson, C., 1999. Petite Delight'Monarda. HortScience, 34(1), 149-150. DOI

DOI: 10.21273/HORTSCI.34.1.149

Davidson C., 2007. Monarda, Bee-balm. In: Anderson N.O. (eds) Flower Breeding and Genetics. Springer, Dordrecht. https://doi.org/10.1007/978-1-40204428-1_28

Dudchenko, V., Svydenko, L., Markovska, O., Sydiakina, O., 2020. Morphobiological and Biochemical Characteristics of Monarda L. Varieties under Conditions of the Southern Steppe of Ukraine. Journal of Ecological Engineering, 21, 8.

Feskov A., Shevchuk M., 2017. Identification of plants' species of genus MonardaL. according to the complex of morphological indications on introduction in the Nikitsky Botanical Gardens //Bull. of the State Nikita Botan. Gard.-No 124. -P. 81-89. ISSN05131634

Heywood, V., 2001. Conservation and sustainable use of wild species as sources of new ornamentals. In: International Symposium on Sustainable Use of Plant Biodiversity to Promote New Opportunities for Horticultural Production 598, p. 43-53.

Kan L., 1996. Russian variety of monarda, floriculture №2, 16.
Korablyova OA, \& MV Lynx, 2013. Biomorphological features of species of the genus Monarda L.. Scientific Bulletin of NLTU of Ukraine, 23 (5), 296-300.

Naydenova G. and Bojanska T. 2014 Selection for resistance to powdery mildew (erysiphe polygoni dc.) in red clover (Trifolium pratense L.) Agricultural science, 47 (No 1), 40-46

Shtiliyanova E., 2005. Floriculture with flower production first special part - flower crops", Dionysus, Sofia, pp. 146, 147 ISBN 9548496607

Silva, D., Ozudogru, E., Reis, M., Lambardi, M., 2018. In vitro conservation of ornamental plants (1). Ornamental Horticulture, 24(1), 28-33.

Stumpf, E., Heiden, G., Iganci, J. , Barbieri, R., Corrêa, L. B, Perleberg, T., Temperado, $E$., 2012. Prospecting native ornamental plants in the Brazilian pampa for use in landscaping and floral art. Acta Horticulturae, 937, 1161-1166.

Tognon, G. Cuquel, F., 2016. Ornamental potential use of Baccharis milleflora and Baccharis tridentata as ornamental cut foliage. Ciencia Rural, 46(1), 70-75.

Wilkins H., Anderson N., 2007. Creation of New Floral Products. In: Anderson N.O. (eds) Flower Breeding and Genetics. https://doi.org/10.1007/978-1-40204428-1_2 